\title{
Challenges and Prospects of Non-Interest (Islamic) Banking System in Nigeria
}

\author{
Michael Takim Otu, Ph.D ${ }^{1^{*}}$, MiebakaNabiebu ${ }^{2}$ \\ ${ }^{I}$ Senior Lecturer, Department of Private \& Property Law, University of Calabar, Nigeria \\ ${ }^{2}$ Doctoral Candidate Faculty of Law, University of Calabar, Nigeria; Industrial Relations and Management \\ Consultant
}

*Corresponding Author: Michael Takim Otu, Senior Lecturer, Department of Private \& Property Law, University of Calabar, Nigeria

\begin{abstract}
The licensing of non-interest (Islamic) Banking, by the Central Bank of Nigeria as an alternative banking system to complement the conventional banking system, which has been in existence since the $18^{\text {th }}$ century, has generated heated debate among Nigerians. This is because of the heterogeneous and the ethnoreligious nature of Nigeria as a country. Consequently this article intends to shed more light on the benefits, challenges and prospects of Islamic banking system in Nigeria. However, the outcome of the above research reveals that dual banking system which is the practicing of non-interest banking alongside with conventional banking system has emerged as the current order at the global financial system. This financial system is been practiced in the most advance jurisdictions of the world and has been proved to be viable and had contributed immensely to the socio-economic development of these countries, when the system is properly regulated and given the adequate enabling environment to operate. Nevertheless the major challenges facing the above banking system in Nigeria is the payment of double taxation and lack of comprehensive legal framework to adequately regulate the system among others. It is therefore recommended that a comprehensive legal frame work should be enacted by the Nigerian National Assembly to properly regulate non-interest banking as well as taking urgent steps to amend our tax laws in other to address the issue of double taxation levied on noninterest (Islamic) banks in Nigeria.
\end{abstract}

Keywords: Islamic Banking, Financial System, Benefits, Challenges, Prospects, Viability, Ethno-Religious, Dual Banking.

\section{INTRODUCTION}

Banks are the most important financial institutions in a modern economy. This is because they perform very important role in the society and in the process significantly influence the level of economic activity, the distribution of income and the level of prices in a country. ${ }^{1}$ The essential services a bank performs includes receiving, collecting, transferring, paying, exchanging, lending, investing or safeguarding money for its customers. ${ }^{2}$ At the global financial market, there operate two financial systems which are the conventional banking system and the Islamic banking system. The conventional banking system is a system where banks receive deposits from savers and lend same to borrowers at interest, a small portion of the interest is used to compensate the depositor while a larger portion is used by the banks. ${ }^{3}$ On the contrary Islamic banking system is otherwise known as Noninterest banking or profit and loss sharing (PLS) banking system. This is because this form of banking system prohibits the payment of interest in all ramifications and then adopts the principle of profit and loss sharing. Thus Islamic banking is defined as a form of banking which is consistent with the principles of Islamic commercial jurisprudence and its application through the development of Islamic economics ${ }^{4}$.

The idea of Islamic banking came up as a result of the exploitative nature of conventional banking system, which is evident in the high interest charged on loans and other financial activities. Consequent upon the above there have been discouragement on investment, funding of low return but socially relevant project's, high level of unemployment, and increase in crime rate. High interest rate is one of the greatest machinery of exploitation at the international community. This is because it makes the economy of most states prone to external manipulation and worsens the internal and 
external debt of such nations ${ }^{5}$. Moreover, the recent global financial crisis which has affected most of the biggest economy of the world practicing conventional interest based banking is a clear indication of its ineffectiveness. This is because despite the effect of the global financial crisis that affected most financial institutions all over the world, Islamic financial institutions were marginally or not affected, rather Islamic banking institutions increased their reserves as well as attracting new clients. ${ }^{6}$

Consequent upon the aforementioned flows of conventional banking system, the Federal Government of Nigeria through the Central Bank of Nigeria (CBN) being the highest regulatory body in the Nigerian banking sector decided to join the race like its counterparts in United Kingdom, USA, Australia, Malaysia and South Africa to dualize the Nigerian banking sector by granting license to banks to offer non-interest financial services, either full-fledge or its subsidiary. The rationale behind this decision by $\mathrm{CBN}$ was to expand the Nigerian capital markets for emerging economics, propel economic development, create more employment opportunities, make the Nigerian banking sector more competitive, poverty alleviation and reduce the effect of credit crunch in the real sector ${ }^{7}$.

In line with the above decision of the CBN to dualize the Nigerian banking sector, approval was granted to the then Habid Bank Plcin 1992 to open a non-interest banking window offering a limited number of shariah-compliant products. In April 2003, the CBN granted Approval-In-Principle (AIP) to Jaiz International Plc to establish Jaiz Bank upon meeting the mandatory capital requirement. This bank became the first full flesh Islamic bank in Nigeria with branches in Abuja (FCT), Kaduna and Kano State and started operation in 2011. Finally, the CBN in January 2011 released the Guidelines for the Regulation and Supervision of Non-Interest Banking in Nigeria as well as two other guidelines modifying the initial once. The said guidelines were issued pursuant to section 28(1)(b) of the CBN $\operatorname{Act}^{8}(2007)$ and the provisions of BOFIA ${ }^{9}$ (1991) as amended: sections 57, 61; 23(1).

However, despite the practice of non-interest (Islamic) banking system in Nigeria for the past 25 years some Nigerians are unaware of the potential benefits, challenges and prospects of the aforementioned banking system. Hence frantic efforts have been made in this article to shed more light on the potential benefits, challenges and prospects of Islamic banking system in Nigeria.

\section{EVOLUTION OF NON-INTEREST (ISLAMIC) BANKING IN NigERIA}

Before Nigerian independence in 1960, they had been strong agitation by Nigerians for indigenous banking and other forms of business. Nevertheless, this struggle for indigenous participation in banks eventually led to the drafting of the CBN ordinance and Banking Act of 1958. However, before independence and immediately after independence conventional banking and other form of industries started operation in the country but Islamic Banking did not. The inability of Islamic banking to start operation then could be traced to lack of trained personnel's and dearth in technical know-how to carryout Islamic banking in Nigeria. ${ }^{10}$

After the Nigerian independence, the advocacy and clamour for the establishment of Islamic banking model became more-stronger. However, it was met with controversies and stiffer challenges. The above clamour was predicated on the establishment of Islamic banks in several Muslim and NonMuslim countries with none in Nigeria despite its large Muslim population. Consequent upon the above agitation the first Islamic bank established in Nigeria was called Muslim Bank West Africa Ltd. This bank operated based on strict Islamic principles in the country. However, its operational license was revoked by the then Federal Commissioner for finance Chief ObafemiAwolowo. Consequent upon this, the CBN which is saddle with the sole responsibility of granting licenses for the establishment of Islamic banking refuse to issue same until recently. ${ }^{11}$ The Muslim Bank West Africa Limited is said to have carried out banking activities in Lagos where it had its headquarters. Accordingly, a building with a bold inscription "Islamic Bank House" is located at Lagos where the bank headquarters was located ${ }^{12}$.

Nevertheless, the evolution of modern Islamic banking in Nigeria dates back to 1991 when the Banks and Other Financial Institutions Act (BOFIA) were enacted. Pursuant to Sections 23 and 61 of BOFIA as amended, recognition was expressly given to banks to carry out their banking activities based on profit and loss sharing. The Act also recognized these Banks as specialized banks. Based on the above provisions of the Islamic banking enabling laws, Habib Nigerian Bank Limited (which later became Bank PHB) was the first bank to take advantage of this enabling Islamic Law by applying for a provisional license in 1992 to carry out banking based on the Shariah principle of profit and loss sharing. Accordingly, same was granted by the CBN in 1997, thus Habib Nigeria Bank Ltd opened a banking window based on Shariah principles ${ }^{13}$. 
In 2004, due to the persistent demand by investors for the establishment of a full-fledge non-interest bank, an approval-in-principle was granted to Jaiz International Plc to establish Jaiz Bank upon meeting monetary capital requirement. ${ }^{14}$ Furthermore, in 2008, CBN issued licenses to Intercontinental Bank Plc, Standard Chartered bank, United Bank for Africa and Habid Bank to operate Islamic banking windows. ${ }^{15}$

In 2010, the CBN classified non-interest banks as specialized banks. Furthermore CBN released new guidelines clarifying the definition of non-interest banking which is not restricted to Islamic banking but also include other forms of non-interest banking which is not practiced according to Islamic Commercial Jurisprudence. ${ }^{16}$ In October, 2010, the CBN joined 11 other Central Banks across the globe and two multilateral banks to establish the International Islamic Liquidity Management Corporation (IILM) The fundamental aim of the IILM was to provide Shariah compliant treasury instruments to address the liquidity management issues of Islamic banks ${ }^{17}$.

In addition, the CBN in January 2011 released the framework for the regulation and supervision of non-interest banking in Nigeria as well as two other guidelines modifying the initial ones due to the massive protest that was directed on CBN. The said guidelines were issued pursuant to section 28(1) (b) of the CBN Act (2001) and the provisions of sections 55, 59, 32 and 61 of BOFIA as amended.

Finally, Islamic banking in Nigeria parades one full-fledged Islamic bank known as Jaiz bank Plc, three Islamic windows namely Sterling bank Plc., Keystone bank Plc and Stanbic IBTC. In insurance and capital market sector we have LOTUS capital which is a full-fledged Islamic fund management company limited and a full window in Cornerstone Insurance Plc. and African Alliance Plc. ${ }^{18}$

\section{BENEFITS OF NON-INTEREST (ISLAMIC) BANKING SYSTEM}

\subsection{Prohibition of the Payment of Interest}

One of the unique features of non-interest banking is the absolute prohibition of the payment of interest. The above prohibition is very crucial because it gives capital to young entrepreneurs without the payment of any interest. This is an outright departure from the high interest paid by entrepreneurs in Nigeria who borrow from conventional banks. ${ }^{19}$

\subsection{Sharing of Business Risk}

With the adoption- of the principle of profit and loss sharing (PLS) Islamic banking equally sharing business risk between the provider of funds (investor) and the entrepreneur (Bank). This is because parties jointly contribute resources for the business, hence share whatever benefit or loss made at the end of the day based on the level of their financial commitment. This is quite different from the conventional banking practice where the entire business risk is completely transferred to the borrower who must pay the principal sum and the interest irrespective of adverse business condition not caused by the borrower. ${ }^{20}$

\subsection{Profitability and Resilience}

It has been reported by the International Monitoring Fund (IMF) that Islamic banks where more profitable than their conventional counterparts in the run up to the global economic crisis of 20052006. This is because of the adoption of the principle of profit and loss sharing and the principle of asset banking which ensures that all funds are asset backed ${ }^{21}$. In the same vein, the resilience showed by most Islamic banks during the global financial crisis of 2005-2006 which affected most of the biggest economy of the world practicing interest based banking is a clear indication of its effectiveness. This is because despite the effect of the global financial crisis on most giant conventional financial institutions, Islamic financial institutions were marginally or not affected. ${ }^{22}$

\subsection{Access to Islamic Development Funds}

The CBN being a full council member of the Islamic Financial Service Board (IFSB) and Nigeria Practicing Islamic (non-interest) banking is a step that will help Nigerian government and other corporate organizations to have direct access to Islamic development funds available globally to finance infrastructural projects, which will bring about more rapid economic development. For instance, on the $15^{\text {th }}$ of March 2002, during the first Islamic Development Bank (IDB) - Nigerian Business Forum, the President of IDB, Dr. Ahmed Al-Madani, announced the banks (IDB) approval of $\$ 98$ million for the implementation of the bilingual education programme in Nigeria in addition to other several intervention projects the bank is undertaking in Nigeria. ${ }^{23}$ 


\subsection{Creation of Employment}

With the establishment of Jaiz Banking Plc, which is currently having three branches in Nigeria, more Nigerians have been giving employments as managers, deputy managers, and director etc, thus reducing the level of unemployment. Furthermore, with the creation of non-interest financial institution unit at the CBN more employment opportunities, training and retraining of manpower in the area have been created. ${ }^{24}$

\subsection{Competition in the Nigerian Banking Sector}

With the commencement of Islamic banking in Nigeria, the monopoly of conventional banking has been broken. Hence there is room for competition in the sector which invariably provides bank customers with more efficient and reliable services ${ }^{25}$. Consequently, Islamic banks have developed unique varieties and competitive financial services that have been tested and accepted globally which were not available before now. For instance Murabaha mode of asset financing, Ijara financing via asset leasing and supply and purchase arrangement through Istisna, Salam etc. These are new products added to the existing banking products and services in Nigeria. ${ }^{26}$

\subsection{New Field of Study}

With the commencement of Islamic banking in Nigeria, many academics, bank staff, chartered accountants, jurists etc have developed interest in Islamic banking, especially on technical areas like how it operates its financial intermediation as well as its principles. Through this, human resource capacity in this area is gradually increasing. Consequent upon the above, a number of training institutions have been established to enhance research in this area of banking. For instance we have the International Institute of Islamic Banking and Finance (IIIBF) at the Bayero University Kano, and Islamic Training Institute at Funtua, Katsina State to enhance academic research ${ }^{27}$. Thus, Islamic finance had added value to the intellectual skills of Nigerian business expects, finance scholars, stock brokers, entrepreneurs and lawyers. ${ }^{28}$

\subsection{Reduction of the Apathy among Non-Banking Public}

It has been observed that there are a lot of ideal funds under the pillows of most Nigerian who are not interested in patronizing the existing conventional banking system for fear of straining their relationship with their God. ${ }^{29}$ This is because both Islamic and the Christian faith prohibits the payments or the receipt of interest in all ramification. Consequently it is believed that with the emergence of non-interest banking in Nigeria, there is no doubt that it would help cajole and douse the apathy among the non-banking public to accept the new banking services that recognize banking with ethical precepts as well as recognize their religious values and beliefs. Hence, non-interest banking would make such ideal funds to be useful for productive financial enterprise, because once financial access is enhance, economic activities such as production, employment, distribution and consumption would increase which would inevitably bring about economic growth and development in Nigeria. ${ }^{30}$

\section{Challenges of Non-INTEReST (ISLAMiC) BANKING IN Nigeria}

Non-Interest banking being a new banking technique licensed by the CBN is currently facing the following challenges:

\subsection{The Problem of Islamophobia}

The term Islamophobia is coined from the words Islam and phobia. Consequently, Islamophobia is viewed as an irrational or obsessive fear of Islam or simply the general feelings that everything about Islam is bad, and it is better to stay away from everything that has to do with Islam. The above misconception is further compounded by the horrific deeds of most Islamic fundamentalist who uses, Islam as justification for their acts. Based on the above misunderstanding and prejudice about Islam, any term or concept associated with Islam is automatically opposed by many without objectively studying the concept before arriving at a more rational decision. ${ }^{31}$ This is the same fate Islamic banking is suffering in Nigeria despite it benefit to both the entire Nigeria economy and Nigerian's at large.

\subsection{Lack of Distinct and Comprehensive Legal Framework}

The existing legal framework regulating non-interest banking in Nigeria is not comprehensive enough to properly regulate Islamic finance in Nigeria, hence a major challenge because these laws were 
designed to suit conventional banking system as at the time they were enacted. Thus, it becomes difficult to properly regulate and enforce Islamic financial principle, products and transactions in Nigeria ${ }^{32}$.

\subsection{Ethno-Religious Factors}

Nigeria being a heterogeneous society made up of above 250 ethnic groups with multifaceted languages, culture, traditions and customs. Moreover, the people practice various religions among which the dominant once are Christianity, Islam and African traditional religion ${ }^{33}$. Consequent upon the differences in religion, culture, ideologies and opinions there is frequent clashes and controversies over national issues ${ }^{34}$. It is because of the above ethno-religious factors, which is affecting the noble idea of the CBN dualizing our banking system, in order to create more jobs and make the banking system more competitive. However this noble initiative is rather view as a device to Islamize the nation $^{35}$. This have affected the implementation of government policies especially those that have religious coloration, no matter how beneficial they are to the nation. ${ }^{36}$

\subsection{Disparity in Accounting Standards}

There is disparity between the accounting standards/balance sheet of conventional interest based banks and that of non-interest banks who do not receive interest from customers. Consequently, the CBN has to develop on the work done by the Accounting and Auditing Organization for Islamic Financial Institutions (AAOIFI) who had developed the accounting and auditing standards for Islamic banking products, with the aim of embarking on the training of more chartered accountants who would specialize in Islamic accounting in order to balance their accounts and know how to adequately regulate them. ${ }^{37}$

\subsection{The Problem of Double Taxation}

This is an area where non-interest banking faces serious challenge when compared with conventional banks, because their financial intermediation is asset based. This is because stamp duties and capital gain tax are deductible upon asset transfer in Nigeria. For instance non-interest banks take possession of assets through sale or construction contracts and pay stamp duty for them. Furthermore, when they resell those assets through Ijarah or Mudaraba contract to the new buyer, another stamp duty is charged for the asset transfer. This becomes a serious threat to the success of non-interest banking in Nigeria. ${ }^{38}$

\subsection{Inadequate Awareness about Non-Interest Banking System}

Non-interest banking is facing inadequate awareness on the side of CBN and on the side of Jaiz bank Plc. Consequently, there is lack of adequate information about the objectives, principles, financial intermediation, constitutionality as well as the enormous benefits of the system to Nigeria as a country and its citizens. Due to this lack of adequate information about this banking system, there is unnecessary opposition and lack of nationwide acceptance of the system based on religious issues. ${ }^{39}$

\subsection{Inadequate Human Resources}

Lack of adequate personnel's who are experts in Islamic finance is a major challenge to the Islamic financial system. This is because the survival and development of Islamic banking is dependent on the adequacy of trained personnel's who are knowledgeable in how Islamic banking operates. The above problem is further compounded because only very few universities are offering Islamic finance in Nigeria. Consequently, there is acute shortage of experts in this field of banking, hence detrimental to the operators of the above banking system because it is not cost effective for them to employ experts from outside the country. ${ }^{40}$

\section{Prospects OF ISLAMiC BANKING IN Nigeria}

A critical reflection on the size of Nigerians population which is estimated at over 177,155,754 has Islam and Christianity as the two major religions with Muslim having 50\% population, Christians having $40 \%$ population and traditional religion having $10 \%,{ }^{41}$ is a clear indication that Nigeria has the prospect of becoming the hub of Islamic finance in Africa. The following prospects of Islamic banking are easily discernible in Nigeria:

- The government's determination to revamp Nigeria's ailing infrastructure and the massive investment in such critical sectors as power, roads, railways etc. as well as the emphasis on Public Private Partnership (PPP) offers opportunities for Islamic banks to participate using various Shariah compliant financing modes especially Sukuk, Ististia, Mudaraba, thus contributing to the economic development of Nigeria. ${ }^{42}$ 
- The recent financial sector reforms have contributed significantly in restoring confidence and stability of the Nigerian financial system. Islamic banks are expected to benefit from this financial reforms hence contribute positively in socio/economic development. ${ }^{43}$ The potential role of the Islamic banking in the corporate social responsibility may propelits socio-economic contributions to the economy, especially in the provision of free services to the indignant under the philanthropic sector activities. From this pedigree, Islamic ${ }^{44}$ banking has great potentials in fostering development in the social sector by participation in financing of socio-economic programmes like youth skills acquisition programmes, women empowerment, and micro and small-scale industrial development programmes.

- The emergence of non-interest (Islamic) banking in Nigeria as complementary alternative to Conventional banking system would allow citizens to have different credit choice among different types of banking structures in the country; hence it would deepen and diversify the financial system for the benefits of all. This is because from the CBN new banking model, non-interest banking is just like any of the existing banking techniques such as microfinance banks, mortgage banks, development banks and merchant (investment) banks in the industry in which any interested party can participate at any point in time out of their own decision. More significantly, Muslim and non-Muslim population which yearn for Islamic finance services would have the opportunity of the availability of the non-interest banking services ${ }^{45}$.

- Islamic banking is expected to contribute significantly in developing micro credit schemes towards improving the overall communities. Micro credits schemes have greater tendency to alleviating poverty by fostering income generation activities and reducing unemployment rates among the poor in communities. ${ }^{46}$

- The growth of Islamic banking in Nigeria will foster flow of development funds from Islamic banking system of the world. This development fund is provided by Islamic Development Bank (IDB) which provides development funds for infrastructural projects to member countries. Nigerian Government and corporate organizations would have access to Islamic development fund available in the international community to finance infrastructural projects. Such development resources will flow through the local Islamic banking system to the beneficiaries.

- The huge infrastructure requirement poses Sukuk (Islamic bonds) opportunities in Nigeria, besides other Shari'ah-compliant investment opportunities. This is because the Sukuk market has emerged as an important form of intermediation in Islamic finance. Government and the private sector may draw developmental resources through issuance of Sukuks, which could finance critical infrastructure investment in the utilities sectors, in particular for water and power projects, and in the services sector, in education, healthcare and transportation, as well as in the agricultural sector. ${ }^{47}$

- An interesting fall- out of the global financial crisis is the growing interest and demand for Islamic financial products and services across the world. Amid the crisis, Islamic financial institutions have displayed strong resilience reflecting their conservative approach to business and focus on the basics of financial intermediation as opposed to innovation. This is a positive move that could feed into the judgment and preference of Nigerians for Islamic banking as an alternative form of financial intermediation ${ }^{48}$.

- The Zero- interest regime in Islamic banking offers a veritable incentive and attractive option for investors who are strangulated by the high lending rates charged by conventional banks. ${ }^{49}$

\section{CONCLUSION}

The role of banks in financial intermediation in the economic advancement of any given country cannot be overemphasized because they are considered as the heartbeat of every prosperous economy ${ }^{50}$. Nigeria being a developing nation with a set target of developing its economy to the level of being rated among the world's top twenty economies by the year 2020, needs a very sound financial system that would cater for all categories of persons in the society.

In order to achieve the vision of Nigerian being among the best twenty economies of the world in the year 2020 (vision 2020), the Central Bank of Nigeria being the apex bank decided to make the Nigerian financial system to be more competitive, through the dualization of the banking system, by 
licensing the operation of Islamic (non-interest) banking like its counterparts, in United Kingdom, United State of America, China, Malaysia, Australia etc. The fundamental aim of the CBN dualizing the banking system is to expand our capital market for emerging economics through the adoption of Sukku (Islamic bond), stimulate favourable competition within the financial system to enhance efficient services to customers, propel economic development, creation of employment, reduction of poverty among Nigerians, reduction of apathy among the non-banking public as well as cushion the effect of credit crunch in the real sector of the economy.

However, the move by the CBN to introduce dual banking system with its attendant benefit to the country has generated a lot of controversies because of the ethno- religious nature of Nigeria. However it has been discovered in the course of this research that both the conventional and the noninterest banking system offer similar service as it relates to making of profit and collection of deposits from their clients ${ }^{51}$. However, the differ base on the fact that, while conventional banks receive and pay interest, non-interest banks are prohibited from receiving or paying interest $\mathrm{t}^{52}$. while the former completely transfer the entire business risk to the borrower, who must pay the principle and the multi layers of interest at a particular date irrespective of what the business outcome looks like, the later share profit and losses of the business depending on the rate of financial involvement and the rate of return of the business ${ }^{53}$.

Moreover, non-interest banking is an alternative form of financial intermediation which has been tested to be viable globally; this is because it is capable of impacting positively in the Nigerian economy because of the prohibition of the payment of interest, and its principle of profit and loss sharing. Consequently, it would make money and other financial services which were not initially provided by conventional banks available to young entrepreneurs who could not afford to pay the huge interest fixed by conventional banks.

Nevertheless, dual banking system is the current order of the global economic system. This form of banking system is been practiced by the best economy in the world and has been proved to be viable when given an enable environment, properly regulated and adequate awareness being created about the system. However, the state of acceptability of non-interest banking is slow and fraught with many challenges. This is because of lack of adequate awareness of the basic principles, and mode of operation. Furthermore, an appraisal of the institutional and legislative framework regulating noninterest banking in Nigeria has revealed that there are lacunas in the laws that needed to be addressed. These lacunas are the major challenges hindering the rapid development of non-interest banking in Nigeria. For instance, the frame work for the regulation of non-interest financial institutions has not been able to address the issue of double taxation of non-interest banking products, nor our tax laws been amended, with a view to addressing the issue of double taxation for non-interest banking products. Consequently, stamp duties and capital gain tax are been deducted when non-interest banks purchase assets through sale contracts, same is also deducted when non-interest banks re-sell those asset to new buyers through Ijarah (Lease contracts). This has seriously affected the productivity of non-interest banking system in Nigeria. It is therefore hope that when the above mentioned recommendations are taken into consideration by the Nigerian Federal Government Islamic banking would contribute more meaningfully to the socio-economic development of Nigeria.

\section{REFERENCES}

[1] M. Iqbal, and P. Molyneux,. "Thirty Years of Islamic Banking: History, Performance and Prospects". (New York: Palgrave Macmillan, 2005) at pp 20-25

[2] A. B. Dogarawa, "Critique of the Non-Interest Banking Framework in Nigeria." ISRA International Journal of Islamic Finance, 5, no 1, (2013): at 115.

[3] H. Aytug and H. Oztwa "Conventional Banks Versus Islamic Banks: What Makes the Difference?." In H.A. El-KaranshawyEtal.(Eds) “ Islamic Banking and Finance” ( Bloomsbury Qatar Foundation ,2015) at pp 21-24

[4] Y. O. Lawal "Islamic Banking in Nigeria: A Stimulant For Mobilizing Funds For Productive Activities" American Journal of Social and Management Science at pp. 132-133 available at <http://www.scihub.org/ AJSMS> last visited on the $12^{\text {th }}$ of June, 2016 at 4:30am

[5] S. T. Tunji "Islamic Banking as a Panacea for Economic Instability in Nigeria". Arabian Journal of Business and Management Review (Nigerian chapter) vol. 1, No. 3 (2012) at p. 84 
[6] A. Bello and M. Abubakar "Challenges and Solutions of Islamic Banking System in A Pluralistic Secular Country Like Nigeria". Mediterranean Journal of Social Science Vol 5, No. 6 (2014) at p 44

[7] A. N. Adedesi and N. Abdulazeez "A case for Islamic Banking in Nigeria with some lessons from Malaysia".African Journal of Social Science vol 4 No. 4 (2014) pp. 105-106.

[8] Draft framework for the regulation and supervision of non-interest banks in Nigeria. BSD/DIR/Gen/NIB/ 01/008 March 4, 2009.

[9] CBN Act "Central Bank of Nigerian Act 2007" in Federal Republic of Nigerian Official Gazette No. ss vol. 94. Government Notice No. 34 pp. A63-91

[10] The first legislation on banking was Bank Ordinance, 1952 which was aimed at regulating banking operations especially the monopoly of Bank of British West Africa (BBWN) that changed to standard bank and finally $1^{\text {st }}$ Bank ILCL.

[11] M. A. Karkarku "The Need for Islamic Banking in Nigeria" being a paper presented at the $1^{\text {st }}$ international conference on Islamic Banking and Finance organized by Crescent University Abeokuta 2010 at pg. 7.

[12] D. A. Ajayi "Law and Practice of Banking" (Ibadan: Adyp Corporate Bureau, 1999) p. 57

[13] F. Bello "Emerging Opportunities for Divine Banking in Nigeria" being a paper presented at the first orientation" seminar on Islamic Banking and Finance in Nigeria, Held on $25^{\text {th }}$ Nov., 2000 in Kano Nigeria. See pp. 15-16.

[14] A. Onafowokan "Non-interest (Islamic) Banking: Principle and Practice" (Lagos" Kings \& Queens Associates, 2003) pp. 71-72.

[15] I. T. Sampson "Legitimizing Islamic Banks: The Controversy over Islamic Banking in Contemporary Nigeria" Canadian Journal of African studies available at http//dx.doi.org/10.1080/00083968.2013.831364 at p. 5. Last visited on the $13^{\text {th }}$ of August, 2016.

[16] CBN Framework for the Regulation and Supervision of Institution Offering Non-interest financial services in Nigeria". Website: <www.cbn.gov.Ng> last visited on the $28^{\text {th }}$ of October 2011 at 4:30 am

[17] Ibid at p. 2

[18] S. A. Mukail "The Islamic Finance Industry In Nigeria From History, Mystery To Future Reality" available at http://blog thomsonreuters.com/index.php/Islamic-banking-in-Nigeria-progress and prospects last accessed on $16^{\text {th }}$ of August 2016 at 3.10am see p. 1.

[19] Iqbal\&molyneuxop cit. at pp 37- 39.

[20] Jabber op cit. at pp 15-17.

[21] IMF Survey magazine 2009 "IMF research posted on Oct. $4^{\text {th }} 2010$ available at ww.IMF.org/external/pubs/ $\mathrm{F}+/$ survey/50/2010/res10004/Last visited on $2^{\text {nd }}$ June, 2016 at 4:30pm.

[22] A. Bello \& M. Abubakarop cit at p. 4

[23] Aliyuop cit at pp. 150-151

[24] ibid

[25] L. S. Sanusi "Islamic Finance in Nigeria, Issues and Challenges". Lecture delivered by the Government Central Bank of Nigeria, at markfield institute of higher education beicester, UK (2011) at p. 17

[26] Aliyu Op cit. at pp 150- 151.

[27] Ibid at 151.

[28] A. Adeoyeldowuop cit. at p. 12

[29] A. Kelani "Understanding interest-free banking in Nigeria, the punch (Nigeria) of $6^{\text {th }}$ July, 2011 available at punch on the web.com. Last accessed on $10^{\text {th }}$ April, 2017 at 7:43am

[30] Aliyu Op cit. at p 151.

[31] A. Ernest "Promoting Islamic Finance and Islamic Banking: A legal analysis of the potential for Islamic banking products in Germany". Available at http://www.presseportal.de/pm/59290/1298586/iirudent schland-gmbh/rss. last visited $30^{\text {th }}$ March,2017 at 4:20pm

[32] A. Bello \& M. Abubakar "Challenges and Solutions to Islamic Banking System in a pluralistic - secular country like Nigeria. Mediterranean Journal of Social Sciences vol. 5 No. of 6 April 2014 at pp. 31-32.

[33] SanusiOpcit see p. 5, B. O. Fati "Can Islamic Bank work in Nigeria". Journal of Sustainable Development in Africa vol. 14, No. 2 (2012) at pp. 28-29.

[34] The Nigerian year book (Abuja: Government Press, 2007) at p. 6

[35] This day, Nigerian newspapers of May 19, 2004, reported that between 1987-2004. Ethno-religious conflicts/crisis lead claimed many lives with property destroyed in Lagos, Ogun, Oyo, Ondo, Kwara, Kaduna etc. Available at thisday@ Novanet.ng.see p. 1. Last visited on the $18^{\text {th }}$ April,2017 at 2:30am.

[36] Sanusiop cit. at pp. 19-21. 
[37] Fatiop cit, see p. 37; Bello and Abubakarop cit at p. 31.

[38] Fatiop cit. at pp 37-38.

[39] Bello and Abubakarop cit. at 33.

[40] Ibid at 33.

[41] Nigerian - people 2016, CIA world fact book - available at www.theodora.com/wfb/current/Nigeriapeople. html. last visited on the $16^{\text {th }}$ of June 2016 at about 3:10pm

[42] S.L. Sanusi “"Islamic Finance in Nigeria: Issues and Challenges'. Lecture Delivered at Markfield Institute of Higher Education (MIHE), Leicester, United Kingdom. June, 2011. At p 17

[43] Ibid at pp 17-19

[44] N AAbdullahi "Islamic Banking In Nigeria: Issues And prospects" Journal of Emerging Economies and Islamic Research available at www.jeeir.com last visited on $8^{\text {th }}$ August 2015.

[45] Ibid at pp 10-12

[46] Ibid at pp 12-14

[47] Ibid at pp 9-11

[48] A. Bello and M. Abubakarop cit at p 44

[49] Sanusiop cit at pp $17-18$

[50] M. Iqbal, and P. Molyneuxop cit at pp 20-25

[51] U. I. Aburime "Islamic Banking: Theories, Practices and Insights for Nigeria". International Review of Business Research papers vol. 5, No. 1 of Jan. 2009 at pp. 321-339.

[52] M. Hanif "Differences and similarities Between Islamic and Conventional Banking”. International Journal of Business and Social Science, Vol. 2 No. 2.Feb.2011 at p. 167 available at www.isbssnet.com.Last visited on $10^{\text {th }}$ April 2017 at 4:30am.

[53] K. Khir, L Gupa and B Shanmugam "Islamic Banking: A Practical Perspective" (Kuala Lumpar: Pearson MalyasiaSdn. Bhd, 2008) at pp 20-22.

\section{AUTHOR'S BIOGRAPHY}

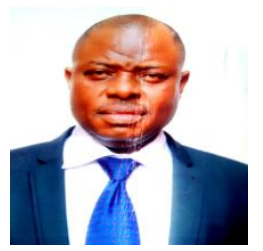

The author Dr. Michael Takim Otu was born $11^{\text {th }}$ October, 1964 in Boki Local Government Area of Cross River State- Nigeria. He has the following academic qualifications to his credit: first school leaving certificate, (FSLC); 1976; WASC 1982; N.C.E. 1983; B. ED. (Hons) 1989; PGDM 1997; LL.B (Hons) 1997; MBA 1999; B.L, 2001; LL.M 2005; Ph.D. Law 2015. He is a multi-disciplinary scholar and an established authority in Law of Secured Credit Transactions/ Property Law. $\mathrm{He}$ is currently a Lecturer in the Department of Private and Property Law, Faculty of Law and Chairman Faculty of Law graduate committee, University of Calabar-Calabar. He is married with children.

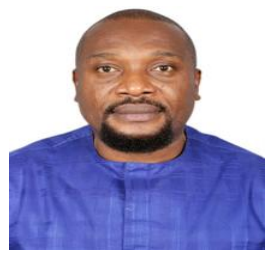

Miebaka Nabiebu LLB, Rivers State University, BL, LLM, PGD, Strathclyde University, Scotland, United Kingdom, Doctoral Candidate, Faculty of Law, University of Calabar, Nigeria; Industrial Relations and Management Consultant.

Citation: Michael Takim Otu, MiebakaNabiebu. "Challenges and Prospects of Non-Interest (Islamic) Banking System in Nigeria". International Journal of Humanities Social Sciences and Education (IJHSSE), vol. 6, no.7, 2019, pp. 100-108. doi: http://dx.doi.org/10.20431/2349-0381.0607011.

Copyright: (C) 2019 Authors. This is an open-access article distributed under the terms of the Creative Commons Attribution License, which permits unrestricted use, distribution, and reproduction in any medium, provided the original author and source are credited. 